\title{
Evaluation of the State of Ecological Sphere Vital Activity in the Medium-Size Cities
}

\author{
Mykola Klymenko ${ }^{1}$, Oleksandr Klymenko ${ }^{1}$, Ludmyla Klymenko ${ }^{1}$, Maria Kopiy ${ }^{2}$, and Ilya Tsinivskiy ${ }^{1}$ \\ ${ }^{1}$ National University of Water and Environmental Engineering, 33028, Ukraine \\ ${ }^{2}$ Ukrainian National Forestry University,79057, Ukraine
}

\begin{abstract}
The analysis of the state of ecological sphere development in the medium-size cities of Ukraine certifies the presence of negative tendencies there, exactly, the decrease of population quantity, the growth of numbers of movable sources and the level of population morbidity. There has been suggested a scale to make qualitative and quantitative evaluation of the changes of ecological sphere state according to which indices ascertain the correspondence with their states: $1,0-0,75$ as high, $0,749-0,50$ as medium, $0,499-$ 0,25 as less than medium, $0,249-0$, as low. It is revealed that high level of ecological development refers to Ivano-Frankivsk $(0,777)$, which is the leader according to the level of planting greenery, the lowest accumulation of waste materials of the $1 \mathrm{st}-3 \mathrm{~d}$ level of danger, the lowest emission of pollutants into atmosphere from stationary and movable sources. Melitopol has medium level $(0,57)$ and is the leader as to the indices of drinking water consumption and is characterized by good indices concerning the waste treatment, considerable expenses spent on nature-protecting activity and low amount of pollutant emission into atmosphere. The cities of Lutsk and Rivne are characterized by lower than medium level of the development of ecological sphere vital activity $(0,482 ; 0,384$ in the year 2017 correspondingly), because of a great amount of pollutants emission into atmosphere, low level of planting greenery. The city of Rivne, besides, has the highest indices as to the assumption of waste materials and the least expenses on nature-protecting measures. It is ascertained that the influence of destimulators and stimulators on the level of development of medium-size cities ecological sphere is described by dependencies which look like straight lines at the coefficients of determination $\mathrm{R}^{2}$ from 0,381 to 0,721 .
\end{abstract}

\section{Introduction}

The successful development of regions and cities based on sustainable development is possible only under the conditions of analytical studies of the dynamics of indicators that characterize the state of social, economic, and environmental spheres of its lives. Based on the results of research and SWOT-analysis for regions and cities, it is possible to formulate a strategic vision, mission, strategic and operational goals, as well as tasks for their development, which will contribute to their sustainability in the short and long term [1-6].

A number of scientists studied and assessed the state of the ecological,economic and social sphere of cities and regions, namely, Z.Gerasymchuk, I. Condius (2010),L. Shen, J.J.Ochoa, M.N.Shah, andX. Zhang (2011), K. Mori, A. Christodoulou (2012), U.Mörtberg, J.Haas, A.Zetterberg, J.P.Franklin, D.Jonsson (2013),M. Klymenko, A.Pryshchepa, N.Khomich (2014),T. Tolstykh, L.Gamidullaeva, N. Shmeleva and Y. Lapygin (2020) [5-10].

According to the recommendations of Z.V. Herasymchuk, OV. Sereda for the analysis of the state of development of the ecological sphere we have chosen medium-sized cities [1].

* Corresponding author: o.m.klymenko@nuwm.edu.ua
In recent years, developing Strategies for Sustainable Development of Cities of Ukraine, researchesprovide the evaluationof the state of the environmental sphere based on the results of surveys accompanied by standard and declarative decisions to improve the state of this sphere.

In our opinion, the assessment of the state of the ecological sphere of life of cities should be carried out using quantitative and qualitative indicators that characterize the state of this sphere in the past and in the future.

To achieve this goal, medium-sized cities of Ukraine with a population of 150 to 250 thousand people were selected for the research, which has common features in terms of levels of sustainable development and environmental safety.

Conducting the study of the ecological sphere of life of medium-sized cities is due to the fact that in recent decades, against the background of climate change and the growing number of mobile sources of air pollution, there was the negative impact on the functioning and development of their socio-economic and ecological system. According to the research many scientists have shown a growing trend in urban morbidity of respiratory diseases and circulatory systems, diseases of allergic origin, tumors, due to increasing emissions of pollutants into the atmosphere from stationary and mobile sources [6,11-14]. 
Accordingly, it is extremely important and urgent to solve problems related to the study of the functioning and development of the environmental sphere, assessment and forecasting of its changes in the nearest future.

Aim of the research was providing of a comparative estimation of the state of the environmental sphere of medium-sized cities in Ukraine.

\section{tasks:}

Achieving the goal involved studying the following

- substantiation of the methodology for assessing the state of the ecological sphere of medium-sized cities;

- conducting a comparative evaluation of the state of the environmental sphere of medium-sized cities;

-developing of a mathematical model of improvement of the ecological sphere of cities.

The object of research is the processes taking place in the environmental sphere of medium-sized cities.

The subject of research is the ecological sphere of medium-sized cities, which is characterized by quantitative and qualitative indicators.

\section{Methodology, research methods}

It is recommended to estimate the state of the ecological sphere of medium-sized cities using quantitative indicators (primary data of statistical materials of the State Statistics Committee of Ukraine) and their ordering in the rating scale which varies from 0 to 1.0 according to the formulas:

$$
\begin{gathered}
\mathrm{X}_{1}=\frac{N i-N(\min )}{N(\max )-\mathrm{N}(\min )} \text { for stimulators }(1) \\
\mathrm{X}_{2}=\frac{N(\max )-N i}{N(\max )-\mathrm{N}(\min )} \text { for destimulators (2) }
\end{gathered}
$$

where $\mathrm{Ni}$ - actual values of the indicator of the ecological sphere;

$\mathrm{N}(\max ), \mathrm{N}(\min )$-maximum and minimum values (for maximum stimulators and minimum destimulators we took quantitative values of indicators that correspond to the best values among medium-sized cities).

Vertical aggregation of indicators at all levels (basic $\left(b_{i}\right)$ in aggregate $\left(\mathrm{AI}_{\mathrm{i}}\right)$, aggregated in the integrated index of the state of the ecological sphere) is carried out using the arithmetic mean (Fig. 1).

We carried out the evaluation of the state of the ecological sphere of the city's vital activity according to developed unified measuring scale, and according to which the state and level of development of the sphere are assessed quantitatively and qualitatively: high level 1.0-0.75; average level 0.749-0.50; below the average level of $0.499-0.25$; low level of 0.249-0.

This scale should also be used to assess the level of sustainable development of the medium-sized city on the basis of the integrated index of the level of sustainable development of the city (IILSDC) calculated as the geometric mean of the indices of social, economic, environmental spheres.

In addition, methods of analysis, comparison, correlation, and regression analysis using Microsoft Excel and Statistics were used.

\section{Research results}

To assess the state of the ecological sphere of life of the city, we used seven indicators, namely: emissions of pollutants from stationary sources; emissions of pollutants from mobile sources of pollution; waste generation of I-III hazard classes (destimulators); the level of freshwater use; capacity of treatment facilities; the total area of green areas and plantations; capital investment and running costs for environmental protection (stimulants). With vertical folding, seven indicators are aggregated into five criteria, namely: air emissions, water use, waste management, the level of urban landscaping, the cost of environmental activities.

The integrated index of development of the ecological sphere of life of the city is calculated as the arithmetic mean of seven indicators. The results of the study of the indicators of the four medium-sized cities are presented in the table1, 2.

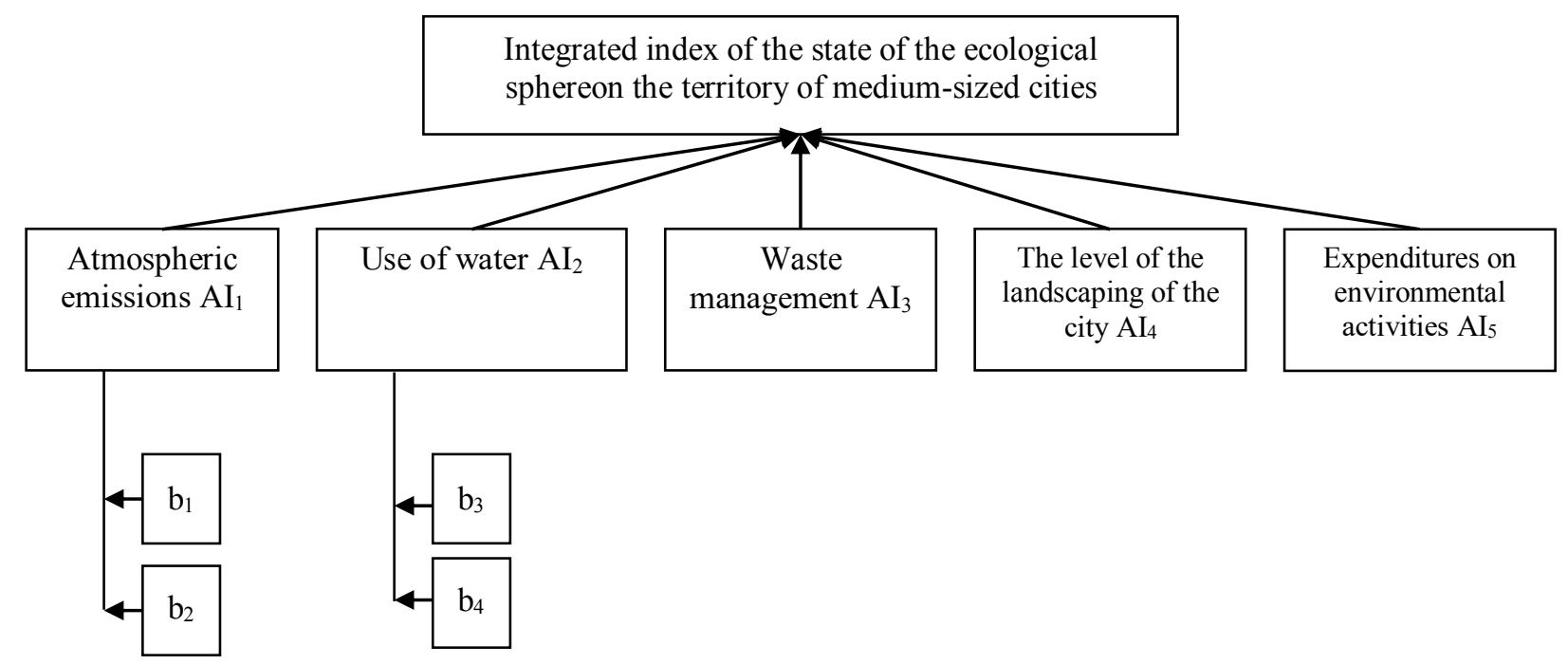

Fig.1. Scheme of calculation of the integrated index of the ecological sphere of the territory of medium-sized cities 
Table 1.Theresults of the assessment of the level of sustainable development of the ecological sphere of medium-sized cities

\begin{tabular}{|c|c|c|c|c|c|c|c|c|c|c|c|c|c|}
\hline \multirow{2}{*}{ Criteria } & \multirow{2}{*}{ Indicators } & \multicolumn{3}{|c|}{ Ivano-Frankivsk } & \multicolumn{3}{|c|}{ Lutsk } & \multicolumn{3}{|c|}{ Melitopol } & \multicolumn{3}{|c|}{ Rivne } \\
\hline & & 1 & 2 & 3 & 1 & 2 & 3 & 1 & 2 & 3 & 1 & 2 & 3 \\
\hline \multirow{3}{*}{$\begin{array}{l}\text { Atmospheric } \\
\text { emissions, } \mathbf{A I}_{\mathbf{1}}\end{array}$} & $\begin{array}{c}\text { Emissions of } \\
\text { pollutants from } \\
\text { stationary sources, } \\
\mathrm{kg} / \text { person }\end{array}$ & 1.0 & 1.0 & 1.0 & 0.82 & 0.75 & 0.789 & 0.84 & 0.65 & 0.745 & 0.01 & 0.01 & 0.01 \\
\hline & $\begin{array}{c}\text { Emissions of } \\
\text { pollutants from } \\
\text { mobile sources, } \\
\text { kg/person }\end{array}$ & 0.52 & 1.0 & 0.76 & 0.01 & 0.01 & 0.01 & 0.84 & 0.66 & 0.75 & 1.0 & 0.86 & 0.93 \\
\hline & $\mathbf{A I}_{1}$ & 0.76 & 1.0 & & 0.42 & 0.38 & & 0.84 & 0.66 & & 0.50 & 0.44 & \\
\hline \multirow{3}{*}{ Use of water, $\mathbf{A} \mathbf{I}_{\mathbf{2}}$} & $\begin{array}{c}\text { Level of freshwater } \\
\text { use, } \mathrm{m}^{3} / \text { person }\end{array}$ & 0.01 & 0.01 & 0.01 & 0.16 & 0.16 & 0.16 & 1.0 & 1.0 & 1.0 & 0.82 & 0.79 & 0.805 \\
\hline & \begin{tabular}{|c|} 
The capacity of \\
treatment facilities, \\
$\mathrm{m}^{3} /$ person \\
\end{tabular} & 0.40 & 0.46 & 0.43 & 0.34 & 0.32 & 0.33 & 0.01 & 0.01 & 0.01 & 1.0 & 1.0 & 1.0 \\
\hline & $\mathbf{A I}_{2}$ & 0.21 & 0.23 & & 0.25 & 0.24 & & 0.50 & 0.50 & & 0.91 & 0.90 & \\
\hline $\begin{array}{c}\text { Waste } \\
\text { management, } \\
\mathbf{A I}_{\mathbf{3}}\end{array}$ & $\begin{array}{l}\text { Waste generation } \\
\text { of I-III hazard } \\
\text { classes, } \mathrm{kg} / \text { person }\end{array}$ & 1.0 & 0.98 & 0.99 & 0.96 & 1.0 & 0.98 & 0.88 & 0.80 & 0.84 & 0.01 & 0.01 & 0.01 \\
\hline $\begin{array}{l}\text { The level of } \\
\text { urban } \\
\text { landscaping, } \mathbf{A I}_{\mathbf{4}}\end{array}$ & $\begin{array}{c}\text { The total area of } \\
\text { greens and } \\
\text { plantings, } \mathrm{m}^{2} / \\
\text { person }\end{array}$ & 1.0 & 1.0 & 1.0 & 0.23 & 0.24 & 0.235 & 0.01 & 0.01 & 0.01 & 0.01 & 0.01 & 0.01 \\
\hline $\begin{array}{l}\text { Expenditures on } \\
\text { environmental } \\
\text { activities, } \mathbf{A I}_{\mathbf{5}}\end{array}$ & $\begin{array}{c}\text { Capital } \\
\text { investments and } \\
\text { current } \\
\text { expenditures on } \\
\text { environmental } \\
\text { protection, UAH / } \\
\text { person }\end{array}$ & 0.01 & 1.0 & 0.505 & 0.71 & 0.90 & 0.805 & 1.0 & 0.86 & 0.93 & 0.02 & 0.01 & 0.015 \\
\hline \multicolumn{2}{|c|}{$\begin{array}{c}\text { Integrated index of ecological } \\
\text { sphere }\end{array}$} & 0,563 & 0.777 & 0.671 & 0.461 & 0.482 & 0.473 & 0.654 & 0.57 & 0.612 & 0.41 & 0.384 & 0.396 \\
\hline
\end{tabular}

Note: data for 1 - 2010; 2 - 2017; 3 - the average for 2010-2017.

Table 2. Analysis of indicators of the ecological sphere in terms of variability over time

\begin{tabular}{|c|c|c|c|c|c|c|c|c|c|c|c|c|c|c|c|c|c|}
\hline \multirow{2}{*}{ Criteria } & \multirow{2}{*}{ Indicators } & \multicolumn{4}{|c|}{ Ivano-Frankivsk } & \multicolumn{4}{|c|}{ Lutsk } & \multicolumn{4}{|c|}{ Melitopol } & \multicolumn{4}{|c|}{ Rivne } \\
\hline & & 1 & 2 & 3 & 4 & 1 & 2 & 3 & 4 & 1 & 2 & 3 & 4 & 1 & 2 & 3 & 4 \\
\hline \multirow{2}{*}{$\begin{array}{l}\text { Atmospheric } \\
\text { emissions }\end{array}$} & $\begin{array}{c}\text { Emissions of } \\
\text { pollutants from } \\
\text { stationary sources, } \\
\mathrm{kg} / \text { person }\end{array}$ & 2.07 & 1.65 & 1.8 & $\nabla$ & 4.9 & 4.3 & 4.3 & $\nabla$ & 4.7 & 5.3 & 5.3 & \begin{tabular}{|l|} 
\\
\end{tabular} & 18.02 & 15.0 & 11.7 & $\nabla$ \\
\hline & $\begin{array}{l}\text { Emissions of } \\
\text { pollutants from } \\
\text { mobile sources, } \\
\mathrm{kg} / \text { person }\end{array}$ & 52.7 & 50 & 43.5 & $\searrow$ & 60.7 & 55.4 & 58.0 & $\Delta$ & 47.7 & 48.4 & 48.4 & $\rightarrow$ & 45.2 & 48.4 & 45.5 & 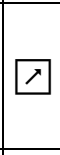 \\
\hline \multirow[b]{2}{*}{ Use of water } & $\begin{array}{l}\text { Level of freshwater } \\
\text { use, } \mathrm{m} 3 \text { / person }\end{array}$ & 65.5 & 60.4 & 60.4 & $\Delta$ & 71.3 & 68 & 68 & $\nabla$ & 101.7 & 108 & 108 & \begin{tabular}{|l|} 
\\
\end{tabular} & 95.4 & 97 & 97.6 & I \\
\hline & $\begin{array}{c}\text { The capacity of } \\
\text { treatment facilities, } \\
\mathrm{m}^{3} / \text { person }\end{array}$ & 220.2 & 219 & 230.4 & $\rightarrow$ & 214 & 213 & 213 & $\rightarrow$ & 173.1 & 172 & 172 & $\rightarrow$ & 292 & 292 & 298 & $\rightarrow$ \\
\hline $\begin{array}{c}\text { Waste } \\
\text { management }\end{array}$ & $\begin{array}{l}\text { Waste generation of } \\
\text { I-III hazard classes, } \\
\mathrm{kg} / \text { person }\end{array}$ & 1.85 & 1.4 & 1.4 & $\nabla$ & 2.0 & 1.3 & 1.3 & $\nabla$ & 2.4 & 2.4 & 2.4 & $\rightarrow$ & 6.7 & 6.7 & 6.9 & $\rightarrow$ \\
\hline $\begin{array}{c}\text { The level of } \\
\text { urban } \\
\text { landscaping }\end{array}$ & $\begin{array}{c}\text { The total area of } \\
\text { greens and plantings, } \\
\mathrm{m}^{2} / \text { person }\end{array}$ & 47.8 & 47.9 & 47.9 & $\rightarrow$ & 28.6 & 28.8 & 28.8 & $\rightarrow$ & 23.2 & 23.2 & 23.2 & $\rightarrow$ & 23 & 23 & 22.9 & $\rightarrow$ \\
\hline $\begin{array}{c}\text { Expenditures on } \\
\text { environmental } \\
\text { activities }\end{array}$ & $\begin{array}{l}\text { Capital investments } \\
\text { and current } \\
\text { expenditures on } \\
\text { environmental } \\
\text { protection, UAH / } \\
\text { person }\end{array}$ & 8.9 & 224 & 224.2 & $\uparrow$ & 140.5 & 202 & 202 & $\uparrow$ & 195.5 & 194 & 194 & $\rightarrow$ & 12.5 & - & 12.5 & $\rightarrow$ \\
\hline
\end{tabular}

Note: The data for: 1 - 2010; 2 - 2011; 3 - 2017; 4 - symbols: $\uparrow$ - rapidly growing; $\nearrow$ - increases; $\rightarrow$ - stable; $\searrow$ - decreases; $\downarrow$ - decreases sharply. 
From the data in the table. 1.2 shows that a high level of environmental development is characterized only by the regional center of the Western region of Ivano-Frankivsk (0.778), which occupies a leading position in the level of landscaping $\left(47.9 \mathrm{~m}^{2} /\right.$ person), according to the criterion of waste management -1.4 $\mathrm{kg} /$ person), with the lowest emissions of pollutants into the atmospherefrom stationarysources (2.07-1.8 $\mathrm{kg} /$ person) and mobile sources (52.7-43.5 kg/person). The average level of ecological development is typical of the city of Melitopol (0.57), which leads in the level of freshwater use (101.7-108 $\mathrm{m} 3$ / person), has good indicators of waste management ( $2.4 \mathrm{~kg} /$ person), significant costs for environmental protection activities (195.5-194 UAH / person) and has low indicators of air pollutant emissions from stationary sources (4.7-5.3 $\mathrm{kg} /$ person) and from mobile (47.7-48.4 kg/person).

The cities of Lutsk and Rivne are characterized by a lower than average level of development of the ecological sphere of life of cities $(0.482$ and 0.384 in 2017, respectively). The reasons for the lower than average level of the ecological sphere of these cities are: for Lutsk significant volumes of emissions from mobile sources (60.7-55.4 kg/person), relatively low level of freshwater use (101.7-108 m3 / person) ); and for the city of Rivne - high volumes of pollutant emissions into the atmosphere (18.02-11.7 kg/person), high levels of waste generation (6.7-6.9 kg/person), low level of landscaping (23- $22.9 \mathrm{~m} 2 /$ person) and the use of small amounts of funds for environmental activities (12.5 UAH / person).
At the same time, it should be noted that for Rivne the positive factors that will improve the level of development of the ecological sphere of the city's life are: reduction of pollutant emissions from stationary sources, an increase of green areas, and environmental costs.

For the city of Lutsk, a competitor for the status of the regional center, promising factors for increasing the level of environmental development may be: reducing emissions of pollutants from stationary and mobile sources, increasing the area of greenery, and environmental costs. As can be seen from Table 2, the cities of Rivne and Lutsk have approximately the same chances, in the long run, to fight for the improvement of the ecological sphere. However, judging by the variability of factors over time, in Lutsk the number of factors whose values are slowly decreasing (disincentives) and increasing (stimulants) during 2010-2017, is much greater than in Rivne. Therefore, the city of Lutsk currently has significant advantages in the development of the environmental sphere compared to the city of Rivne.

Capital investments and current expenditures on environmental protection, UAH / person the sources are described by the equation of descending lines at the coefficients of determination of 0.629 and 0.542 , respectively; the formation of waste I-III hazard classes by the equation of the descending line at $\mathrm{R}^{2}=$ 0.527 (Table 3).

Table 3. Results of correlation and regression analysis of the dependence of the index of development of the ecological sphere of cities on the values of indicators

\begin{tabular}{|c|l|l|c|}
\hline $\begin{array}{c}\text { № } \\
\Pi / \Pi\end{array}$ & \multicolumn{1}{|c|}{ The name of the indicator } & \multicolumn{1}{|c|}{ Type of equation } & $\mathrm{R}^{2}$ \\
\hline 1. & Emissions of pollutants from stationary sources, kg/person. & $\mathrm{y}_{1}=-0.017 \mathrm{x}_{1}+0.652$ & 0.629 \\
\hline 2. & Emissions of pollutants from mobile sources, $\mathrm{kg} /$ pers. & $\mathrm{y}_{2}=-0.00 \mathrm{x}_{2}+0.801$ & 0.542 \\
\hline 3. & Waste generation I-III hazard classes, kg/pers. & $\mathrm{y}_{3}=-0.04 \mathrm{x}_{3}+0.658$ & 0.527 \\
\hline 4. & The total area of green massifs and plantings, m2 / person. & $\mathrm{y}_{4}=0.007 \mathrm{x}_{4}+0.332$ & 0.381 \\
\hline 5. & $\begin{array}{l}\text { Capital investments and current expenditures on environmental } \\
\text { protection, UAH / person }\end{array}$ & $\mathrm{y}_{5}=0.00135 \mathrm{x}_{5}+0.35$ & 0.721 \\
\hline
\end{tabular}

Table 4. Calculation of matrix coefficients to establish the relationship between the index of the ecological sphere

of cities and indicators (2017)

\begin{tabular}{|c|c|c|c|c|c|c|c|c|}
\hline & $\begin{array}{c}\text { Index of } \\
\text { Environmental } \\
\text { sphere }\end{array}$ & $\begin{array}{c}\text { Emissions } \\
\text { of } \\
\text { pollutants } \\
\text { from } \\
\text { stationary } \\
\text { sources of } \\
\text { pollution }\end{array}$ & $\begin{array}{c}\text { Emissions } \\
\text { of } \\
\text { pollutants } \\
\text { from } \\
\text { mobile } \\
\text { sources of } \\
\text { pollution }\end{array}$ & $\begin{array}{l}\text { The level } \\
\text { of } \\
\text { freshwater } \\
\text { use }\end{array}$ & $\begin{array}{l}\text { The } \\
\text { capacity } \\
\text { of } \\
\text { treatment } \\
\text { facilities }\end{array}$ & $\begin{array}{c}\text { Waste } \\
\text { generation } \\
\text { of I-III } \\
\text { hazard } \\
\text { classes }\end{array}$ & $\begin{array}{l}\text { The total } \\
\text { area of } \\
\text { greens and } \\
\text { plantations }\end{array}$ & $\begin{array}{c}\text { Capital } \\
\text { investment } \\
\text { and current } \\
\text { environmental } \\
\text { costs }\end{array}$ \\
\hline $\begin{array}{l}\text { Environmental } \\
\text { index }\end{array}$ & 1.000 & & & & & & & \\
\hline $\begin{array}{l}\text { Emissions of } \\
\text { pollutants } \\
\text { from } \\
\text { stationary } \\
\text { sources of } \\
\text { pollution }\end{array}$ & -0.812 & 1.000 & & & & & & \\
\hline $\begin{array}{l}\text { Emissions of } \\
\text { pollutants } \\
\text { from mobile } \\
\text { sources of }\end{array}$ & -0.216 & -0.146 & 1.000 & & & & & \\
\hline
\end{tabular}




\begin{tabular}{|c|c|c|c|c|c|c|c|c|}
\hline pollution & & & & & & & & \\
\hline $\begin{array}{l}\text { The level of } \\
\text { freshwater use }\end{array}$ & -0.859 & 0.648 & -0.173 & 1.000 & & & & \\
\hline $\begin{array}{c}\text { The capacity } \\
\text { of treatment } \\
\text { facilities }\end{array}$ & -0.147 & 0.687 & -0.356 & -0.049 & 1.000 & & & \\
\hline $\begin{array}{c}\text { Waste } \\
\text { generation of } \\
\text { I-III hazard } \\
\text { classes }\end{array}$ & -0.653 & 0.964 & -0.388 & 0.573 & 0.790 & 1.000 & & \\
\hline $\begin{array}{l}\text { The total area } \\
\text { of greens and } \\
\text { plantations }\end{array}$ & 0.988 & -0.727 & -0.352 & -0.818 & -0.034 & -0.537 & 1.000 & \\
\hline $\begin{array}{c}\text { Capital } \\
\text { investment } \\
\text { and current } \\
\text { environmental } \\
\text { costs }\end{array}$ & 0.660 & -0.974 & 0.275 & -0.505 & -0.826 & -0.990 & 0.554 & 1.000 \\
\hline
\end{tabular}

For stimulants, namely: the total area of green areas and plantations and capital investment and current expenditures on environmental protection, affecting the level of development of the environmental sphere, there are dependencies that have the form of increasing lines with coefficients of 0.381 and 0.721 , respectively.

Other indicators, namely: the level of freshwater consumption per capita, the capacity of treatment plants are values that do not change significantly in cities and are close in value. This information should be taken into account when creating mathematical models for forecasting changes in time of the index of development of the ecological sphere of life of medium-sized cities of Ukraine.

At the same time, we analyzed the matrix coefficients that characterize the strength of the impact of indicators on the index of environmental development of medium-sized cities (Table 4).

As can be seen from the table 3 the highest correlation coefficients were found for destimulators: emissions of pollutants from stationary sources of pollution -0.812 ; emissions of pollutants from mobile sources - 0.216; waste generation of I-III hazard classes -0.653 ; for stimulants: total area of green areas and plantings 0.988; capital investment and current expenditures for environmental protection 0.66 .

Based on the calculated matrix correlation coefficients, we select a system of indicators that together can most fully characterize the integrated indices of the ecological sphere of life of medium-sized cities in Ukraine (Table 4).

The algorithm for constructing a mathematical model, presented in Fig. 2, provides the following structural elements: regression analysis, evaluation of the results, verification of the adequacy of the mathematical model, forecasting the development of the ecological sphere of cities.

According to the calculations, the integrated index of the ecological sphere of life of medium-sized cities (y) depending on the value of indicators of multifactor linear regression at $\mathrm{R}^{2}=0$, has the form:

$$
\begin{gathered}
\mathrm{y}=3,3662-0,00409 \mathrm{x}_{1}-0,01475 \mathrm{x}_{2}-0,01301 \mathrm{x}_{3}- \\
-0,00752 \mathrm{x}_{4}+0,168403 \mathrm{x}_{5}+0,003603 \mathrm{x}_{6}+0,000751 \mathrm{x}_{7}
\end{gathered}
$$

where:

$\mathrm{x}_{1}$ - emissions of pollutants from stationary sources of pollution;

$\mathrm{x}_{2}$ - emissions of pollutants from mobile sources of pollution;

$\mathrm{x}_{3}$ - the level of freshwater use;

$\mathrm{x}_{4}$ - capacity of treatment facilities;

$\mathrm{X}_{5}$ - waste generation of I-III hazard classes;

$\mathrm{X}_{6}$ - total areas of green areas and plantations;

$\mathrm{x}_{7}$ - capital investment and current costs for environmental protection.

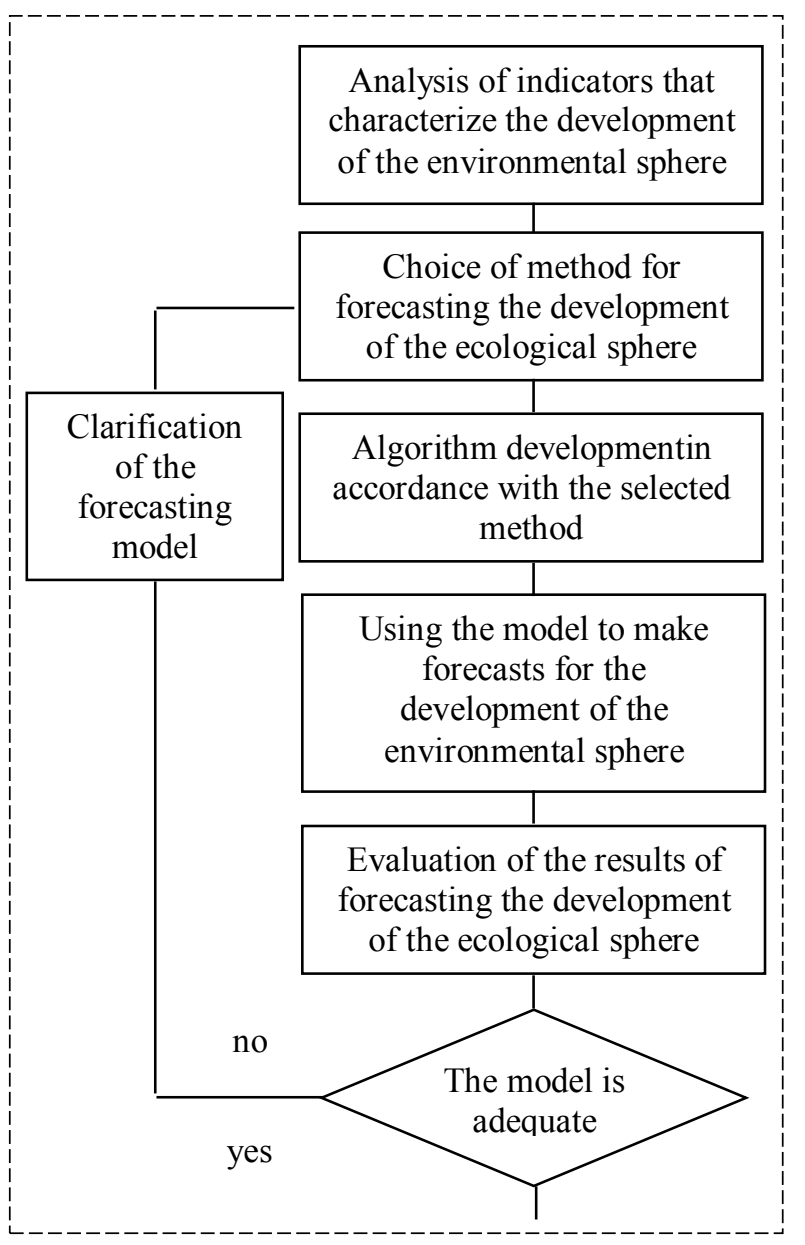

Fig.2.Block diagram of building a mathematical model of development of the ecological sphere of life of medium-sized cities of Ukraine 
The assessment and verification of multifactor linear regression testify to its suitability for sufficiently high accuracy of forecasting the values of the integrated index of the ecological sphere of life (IIESL) of medium-sized cities of Ukraine. The deviation of the established IIESL from the calculated by multifactor linear regression IIESL does not exceed values $+-1 \%$ (table 5$)$.

Table 5. Comparative analysis of integrated indices of the ecological sphere of life (IIESL) of medium-sized cities of Ukraine

\begin{tabular}{|c|c|c|c|c|c|c|c|c|c|}
\hline \multirow{2}{*}{$\begin{array}{l}\text { Name of } \\
\text { the city }\end{array}$} & \multicolumn{3}{|c|}{2010} & \multicolumn{3}{|c|}{2014} & \multicolumn{3}{|c|}{2017} \\
\hline & 1 & 2 & 3 & 1 & 2 & 3 & 1 & 2 & 3 \\
\hline $\begin{array}{c}\text { Ivano- } \\
\text { Frankivsk }\end{array}$ & 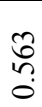 & $\begin{array}{l}8 \\
? \\
0\end{array}$ & $\hat{n}$ & $\stackrel{\circ}{\bullet}$ & 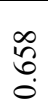 & $\stackrel{n}{?}$ & م & $\frac{2}{2}$ & $\frac{m}{0}$ \\
\hline Lutsk & $\begin{array}{l}\overline{0} \\
+ \\
0\end{array}$ & $\stackrel{\circ}{+}$ & $\begin{array}{l}\text { N̦} \\
\stackrel{1}{1}\end{array}$ & 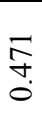 & $\stackrel{f}{\dot{\theta}}$ & $\vec{ก}$ & 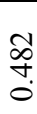 & $\underset{\stackrel{\infty}{+}}{\stackrel{0}{0}}$ & 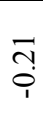 \\
\hline Melitopol & $\begin{array}{l}\text { ț } \\
\text { : } \\
0\end{array}$ & $\begin{array}{l}\tilde{n} \\
\dot{0} \\
\dot{0}\end{array}$ & $\frac{n}{1}$ & $\begin{array}{l}\frac{ \pm}{\sigma} \\
\dot{0}\end{array}$ & $\begin{array}{l}0 \\
\frac{0}{0} \\
\dot{0}\end{array}$ & $\begin{array}{l}\text { ?ै } \\
\text { ? }\end{array}$ & ñ? & $\begin{array}{l}\hat{b} \\
\stackrel{n}{0} \\
0\end{array}$ & $\frac{\infty}{\stackrel{0}{1}}$ \\
\hline Rivne & $\stackrel{F}{\circ}$ & oे & $\begin{array}{l}\stackrel{ \pm}{N} \\
\stackrel{1}{1}\end{array}$ & के & ๗ે? & ñ & 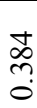 & $\begin{array}{l}m \\
\infty \\
0 \\
0\end{array}$ & ֻे \\
\hline
\end{tabular}

Note: 1. IIES calculated by indicators.

2. IIES calculated by multifactor linear regression.

3. Deviation, $\%$.

Modeling the development of ecological spheres of life of medium-sized cities in the near future using multifactor linear regression (1) provides for cities: Ivano-Frankivsk maintaining a high level of development of this area $(0.828)$ by reducing emissions from mobile sources from 43.5 to $40 \mathrm{~kg} /$ person; Melitopol to ensure the average level of development $(0.72)$ by reducing emissions of pollutants from stationary sources from 5.3 to $4.0 \mathrm{~kg} /$ person and mobile - from 48.4 to $40 \mathrm{~kg} /$ person; Lutsk achievement of the average level of development of the ecological sphere $(0.61)$ by reducing emissions of pollutants from mobile sources from 58 to $50 \mathrm{~kg} /$ person and increasing the area of green areas and plantations from 28.8 to $30 \mathrm{~m}^{2} /$ person; Equal achievement of the average level of development of the ecological sphere $(0.517)$ by reducing emissions of pollutants from stationary sources from 11.68 to $5 \mathrm{~kg}$ / person, mobile sources from 45.5 to $40 \mathrm{~kg} /$ person and increasing the area of green areas and plantations from 22,9 to $30 \mathrm{~m}^{2}$ / person.

\section{Conclusions}

1. To assess the state of the ecological sphere of medium-sized cities, it is recommended to use a measuring scale, according to which the state of its development is assessed quantitatively and qualitatively: high $1.0-0.75$; average $0.749-0.50$; below the average $0.499-0.25$; low $0.249-0$.

2. It is established that the city of Ivano-Frankivsk has a high level of development of the ecological sphere (0.777), the city of Melitopol average (0.57), the city of Lutsk (0.482), and the city of Rivne (0.384) below average, with a tendency to improvement during 2010-2017 for Ivano-Frankivsk, Lutsk and to deterioration for Melitopol and Rivne.

3. Influence of dynamic indicators-stimulators: total areas of green plantings, capital investments and current expenses for environmental protection; as well as indicators-disincentives: emissions from stationary and mobile sources of pollutants, waste generation I-III hazard to the level of environmental development of medium-sized cities is described by dependencies that have the form of descending or increasing lines with coefficients from 0.381 to 0.721 .

4.Modeling of the development of the ecological sphere activity of medium-sized cities of Ukraine should be carried out using a mathematical model in the form of the multifactor linear regression of seven indicators with a coefficient of determination $\mathrm{R}^{2}=$ 0.912 .

\section{References}

1. Z.V. Gerasymchuk, O.V. Sereda. Strategic management of sustainable development of the cities: theory, methodology, practice: monograph. Lutsk, (2014).

2. O. Kariy. Complex development of cities: theory and methodology of strategic planning: monograph. Lviv, (2011).

3. O.A. Karlova. The conception and strategy of socio-economic development of the city. Economic forum (scientific journal). Edition 3, Lutsk: LNTU, (2002). 185-191.

4. Z.V. Gerasymchuk, I.M. Yakhovich. Organizational and economic mechanism of formation and realisation of the strategy of the development of the region: monograph. Lutsk: LSTU, (2002).

5. Z.V. Gerasymchuk, I.S. Condius. Theoretical and applied principles of prognostication of sustainable development of the region: monograph. Lutsk: «Nadstyria», (2010)

6. M. Klymenko, A. Pryshchepa, N. Khomich. Evaluation of the state of Rivne as to the indices of ecological and social monitoring: monograph. Rivne: National University of Water Management and Natural Resources Use, (2014).

7. T.Tolstykh, L.Gamidullaeva, N.Shmeleva and Y.Lapygin.Regional Development in Russia: An Ecosystem Approach to Territorial Sustainability Assessment.Sustainability, 12, (2020).

8. L. Shen, J.J.Ochoa, M.N.Shah, and X. Zhang. The application of urban sustainability indicators - A comparison between various practices. Habitat Int., 35, (2011), 17-29.

9. K. Mori, A. Christodoulou. Review of sustainability indices and indicators: Towards a new city sustainability index (CSI). Environ. Impact Assess. Rev., 32, (2012), 94-106. 
10. U. Mörtberg, J. Haas, A. Zetterberg, J. P. Franklin, D. Jonsson, B. Deal. Urban ecosystems and sustainable urban development-analysing and assessing interacting systems in the Stockholm region. Urban Ecosyst., 16, (2013), 763-782.

11. Luko D. V., Kaskiv M. V. Effects of air pollution on the Rivne population morbidity rate. Man and the environment. Problems of neoecology. № 12, (2012), 35-40.

12. Kozlovska T.Ph. Medical and ecological risk as a way to estimate child's cancer depending on the level of air pollution. II All-Ukrainian congress of ecologists with international participation:

collection of scientifics investigations. Vinnytsia. (2009), 416-419.

13. Stakhiv I.R. Influence of air pollution on health of population from 2001 to 2010 . Theoretical and applied aspects of geoinformatics: collection of scientifics investigations. (2013), 126-132.

14. Shushpanov D. Determinants of health of the population of Ukraine: ecological dimension. Regional aspects of development of productive forces of Ukraine. Issue 22. (2017), 132-142. 